\title{
OUTER SPACE AND COMMON HERITAGE OF MANKIND: CHALLENGES AND SOLUTIONS
}

\author{
Siavash Mirzaee \\ RUDN University \\ Law Institute \\ 6, Miklukho-Maklaya st., Moscow, Russia, 117198
}

The purpose of this research is to provide a comprehensive international legal analysis of the concept of common heritage of mankind as it exists in international space law. In this article scientific methodological approach was used which facilitate determination the whole canvas of the research, identify the main aspects and concepts of the study. The author also widely investigated the concept of common heritage of mankind in the practice of States and international organizations and bodies.

Since mankind succeeded to access outer space and opened the window of this infinite realm, the effort was made to systematize spatial activities by codification and adoption numerous international treaties and declarations. One of the significant result of these efforts was the Agreement Governing the Activities of States on the Moon and Other Celestial Bodies that adopted by the United Nations Committee on the Peaceful Uses of Outer Space by consensus on 5 December 1979, declares the Moon and other celestial bodies to be the common heritage of mankind. This Agreement has never been ratified by any State that engaged in self-launched manned space exploration or has plans to do so and thus has an insignificant effect on spatial activities.

This article analysis the concept of common heritage of mankind that consists of five elements: non-appropriation, international management of resources, sharing of financial and technological benefits, reservation for peaceful purposes and reservation for further generations. It is shown that the Moon Agreement applying the concept of common heritage of mankind to outer space, Moon and other celestial bodies which has been presented by developing countries to preserve essential resources, always been associated with some problems.

Also, on the one hand, there is an attempt to scrutinize these obstacles that prevent applying this concept by paying attention to its challenges. On the other hand, author presents some solutions to strengthen this concept in outer space legal system and motivate space powers to join the Agreement Governing the Activities of States on the Moon and Other Celestial Bodies.

Key words: Moon Agreement; Outer Space Treaty; common heritage of mankind; space law; sharing of benefits; developing countries; celestial body

\section{INTRODUCTION}

The second half of the twentieth century evidenced the realization of a longstanding dream, i.e. the entry into the outer space. On 4 October 1957, Soviet Union's Sputnik I surpassed the earth's gravitational force and entered the outer space 
opening up a new era of scientific and technological civilization popularly called as "space age" [1. P. 92]. After this historical event, the need for a legal regime to govern the space gained importance. The striking feature of the regime to govern the space is the concept of common heritage of mankind, which had its origin in the law of the sea. The concept of common heritage of mankind displays a deep gap between developed and developing countries, when it is surveyed in the outer space framework. Developing countries hold a pivotal position in the creation of this concept, looks at the common heritage of mankind concept as a protecting instrument for vital resources belonging to all human being. Developing countries in the process of implementation of The Moon Agreement ${ }^{1}$ and $\mathrm{UNCLOS}^{2}$ have attempted to use the common heritage of mankind concept in order to generate a legal framework for the exploitation of moon and seabed. This principle ensures developing countries participation in exploitation and management of space and seabed resources and prevent developed countries to monopoly on these areas. Therefore, if the concept of common heritage of mankind turn into a binding principle, applying its elements will challenge all of current spatial activities and make conditions harder for space powers. The aim of this article is to look into the meaning of the concept, and its application to solve the outer space challenges.

\section{RESULTS AND DISCUSSION 2.1. International Space Law}

The success of the space programs of the United States and the Soviet Union have demonstrated the feasibility of space use and has spurred the development of economically practical space activity. While space activity has increased, the world community had increasing difficulty agreeing on specific rules of conduct to govern space use. Existing space law is based on broad theoretical principles contained in the first international agreement governing space use sponsored by the United Nations [ 2 . P. 14]. These broad principles were sufficient to guide space use during the formative years of the space age, but as space activity has flourished, space law has lagged behind. Specifically, states attempting to formulate rules to govern specific space activities have not agreed on the meaning of space law principles [3. P. 403].

One of the earliest declaration concerning the legal status of outer space was that all states are free to explore and use space. ${ }^{3}$ This broad declaration, however, has not proved workable for space activities functionally related to earth. For example, while

\footnotetext{
${ }^{1}$ The Agreement Governing the Activities of States on the Moon and Other Celestial Bodies, 1363 UNTS 21; 18 ILM 1434 (1979); 18 UST 2410.

${ }^{2}$ The United Nations Convention on the Law of the Sea, 1833 UNTS 3 / (1994) ATS 31 / 21 ILM 1261 (1982).

${ }^{3}$ General Assembly. Res. 1721, 16 U.N. GAOR Supp. (No. 17), U.N. Doc. A/5100 (1961).
} 
all states may operate satellites, the world community has not accepted unrestricted satellite use for remote sensing of the earth surface or direct broadcasting of television programs. Another early declaration of space law was that the exploration and use of outer space is the province of mankind ${ }^{4}$. This idea is repeated and expanded in the proposed Moon Agreement, which states that the moon and other space resources are the common heritage of mankind. From each of these declarations flows the proposition that benefits from space shall accrue to all mankind.

\subsection{Definition of Common Heritage of Mankind}

The doctrine of common heritage of mankind can be seen from the words of the great sixteenth/seventeenth century legal scholar Grotius who first defined the doctrine as "God himself says 'speaking through the voice of nature' inasmuch as it is not His will to have Nature supply every place with all the necessaries of life; He ordains that some nations excel in one art and others in another. So, by the decree of divine justice it was brought about that one people should supply the needs of another" [4. P. 309].

Under the common heritage of mankind principle, no one legally owns international areas designated as part of the «common heritage of mankind», though theoretically everyone manages the areas. National sovereignty does not exist, nor its attendant legal attributes and consequences. Under a common heritage of mankind regime, no state or group of states could legally own any part of an international area. The international community, through appropriate treaties or norms of international law, would administer the area [5. P. 228].

There are five elements of the common heritage of mankind concept.

First, the common heritage of mankind could not be appropriated; it was open to use by the international community but was not owned by the international community. Second, it required a system of management in which all users have a right to share. Third, it implied an active sharing of benefits, not only financial but also benefits derived from shared management and transfer of technology, thus radically transforming the conventional relationships between states and traditional concepts of development aid. Fourth, the concept of common heritage implied reservation for peaceful purposes, insofar as politically achievable, and, fifth, it implied reservation for further generations, and thus had environmental implications [6. P. 87].

\subsection{Challenges of Common Heritage of Mankind in Outer Space}

Applying the concept of common heritage of mankind to outer space, moon and other celestial bodies always been associated with some problems. Ambiguous of the

\footnotetext{
${ }^{4}$ Outer Space Treaty. 18 UST 2410, 610 UNTS 205, 6 ILM 386 (1967).
} 
precise meaning of this concept, developed countries' opposition, imperfection and ineffectiveness of Moon Agreement and absence of an international entity to administer this infinite aria are the most important challenges.

\subsubsection{Ambiguous of the Concept}

The concept of common heritage of mankind is not susceptible to a precise definition. It has been subjected to different interpretations by the developed and developing countries. While the developing states gave wider interpretation to the concept, the developed states interpreted it narrowly. Some of the developed states have even expressed the view that the concept is neither realistic nor practical [1. P. 172]. Many jurists have criticized any possible suggestion that the phrase expresses a legal concept [7. P.153].

One jurist has stated that:

"One caution lawyers, diplomats and statesmen should observe is to avoid trying to treat layman's language as if it were formulated in terms of technical legal concepts... On the other hand, the phrase, common heritage of mankind, a layman's formula if ever there was one should be given the greatest respect While it should not, indeed cannot be viewed as a prescription, it can be accepted as an important hortatory message, a kind of policy directive..." [8. P. 819]

It may be observed that the development and growth of the law is, in many cases, a slow process. Terms and phrases which carry only very vague or general connotations may, with the passage of time, ripen into legal concepts and principles. Undoubtedly, the concept of common heritage of mankind will need clarification with particular emphasis on its juridical ramifications. Otherwise, how can we expect the international community to honor the requirements pertaining to mankind which have been incorporated in significant international agreements or to live up to the spirit of United Nations resolutions if there is no clear understanding of at least the basic legal implications? [9. P. 402]

\subsubsection{Developed Countries' Opposition}

Development in the concept of common heritage of mankind always been associated with opposition of developed countries, especially major space powers. This opposition is rooted in political, economic and military reasons.

Regarding political reasons, Daniel Goedhuis, Chairman of the Space Law Committees of both the International Law Association and the World Peace through Law Organization, rejects the view that outer space is now recognized as the common heritage of mankind. He argues that an interpretation of this kind would oblige every state to share with every other state the advantages and benefits flowing from their space activities. In Goedhuis view this would mean states have "surrendered vital sovereign powers... and have agreed to a fundamental change in the political structure 
of international society" [3. P. 424]. In like manner, Arvid Pardo, one of the founders of the common heritage of mankind concept has claimed that it challenges the structural relationship between rich and poor countries and amounts to a revolution not merely in the law of the sea, but also in international relations [10. P. 559].

Economic reasons of developed countries' opposition have reflected on the issue of equitable benefit sharing as one of the most important elements of the concept of common heritage of mankind. Unfortunately, there exists some misinformation about the concept of equitable benefit sharing, even in some official circles. For example, the United States Army Space Reference Text on Space Policy and Law mentions that the Moon Agreement "was signed by five countries but not the United States or the Soviet Union. It states that the Moon is a common heritage for all mankind which implies that all nations would share equally in any benefits derived from Moon exploration. If the United States signed this Agreement, it would be hard to get private firms to invest in future Moon projects if they had to divide the profits" [11. P. 104]. Also developed countries have their own interpretation on the concept of benefit sharing. For example, Germany and France presented a paper in 1995 which had two central points: first, that nations act freely in determining their international co-operation; and second that they should choose the most efficient means of resource allocation. The Franco-German proposal made it clear that the developed nations continued to demand free choice as to what projects their funds would be directed, and to which nations [12. P. 64].

Peaceful uses and demilitarization of outer space is another reason for disagreement of developed countries concerning common heritage of mankind concept. Acceptance of this concept implies prohibition of all activities in this area with the aim of militarization. Spatial activities of developed countries in the past and now indicate that their exploitation and exploration in the outer space is related to military purposes and they prefer this aspect of activity more than other aspects. Firing a ballistic missile by China on one of its meteorological satellite in 2007 and destroying a reconnaissance satellite by United States in 2008 testify to this fact that their initial goal is militarization of outer space.

\subsubsection{The Ineffectiveness of Moon Agreement}

Moon Agreement is the last international Agreement in the field of Space Law. The importance of the Agreement on the grounds that there are many consideration to the framework of the concept of common heritage of mankind compared to other documents. The Moon Agreement is contentious because it amends the legal status of the Moon, from the 'province of all mankind' under the Outer Space Treaty, to the 'common heritage of mankind' [13. P. 7]. Although it was adopted by the United Nations General Assembly, but it has not welcomed by the international communities. The most important reasons for ineffectiveness of Moon Agreement are failure to comply with realities and containing the concept of common heritage of mankind. 
Earlier space treaties were based on contemporary problems and drew on factual testimony from experts. In the Moon Agreement drafters attempted to develop binding rules decades ahead of the necessary technology. If history is a guide, then the international community must wait for natural resource exploitation to become a contemporary problem on which experts can offer informed expertise before regulation can proceed [14]. In the time of drafting of Moon Agreement, the necessity of complying the provisions with realities were supported by the Soviet Union. The Soviet Union took the position that since exploitation of the moon would not be economically feasible for some time, provisions for such exploitation were premature. The United States favored the inclusion of such provisions because it believed that future conflicts could be avoided by present action [3. P. 419]. Therefore, it seems that some of provisions of the Agreement neither in the time of adoption nor in the present time have not much compliance with realities. Some countries, including Russia, think these provisions are inadequate because they do not address all possible situations. Accordingly, they have suggested that a new, comprehensive Agreement should be negotiated [15. P. 232].

The most important reason for ineffectiveness of Moon Agreement is related to including the concept of common heritage of mankind (Article 11, Paragraph 1) against countries with advanced space technology. In order to fulfill this principle, the Agreement states that an international regime should be founded with the aim of the development of the natural resources of the moon, the rational management of those resources, the expansion of opportunities in the use of those resources and an equitable sharing by all States Parties in the benefits derived from those resources, whereby the interests and needs of the developing countries (Article 11, Paragraph 7). It has been one of the main reasons for disapproval of space powers and it has led to the failure of the Agreement. The developed nations fear that adoption of the common heritage principle in space exploration would tantamount to transfer of wealth, political power, and technology from the space-faring nations to the Third World countries [16. P. 213]. This approach made dissatisfied those private firms that they have undertaken spatial researches. For example, the L5 Society, as a private firm succeed to convince the Senate Foreign Relations Committee of the United States to oppose signing of the Moon Agreement [17]. In addition to the aforementioned subject, there are more reasons for developed countries disapproval regarding Moon Agreement as following: First, Principles enshrined in the Moon Agreement are a departure from traditional property rights. Second, the Agreement would establish guiding principles for the international regime inimical to the interests of private enterprise. Third, the Agreement gives to other countries political control over commercial exploitation of the moon [3. P. 421].

\subsubsection{Lack of an International Entity to Administer Outer Space}

Given that common heritage of mankind resources belongs to the international community as a whole, the second common heritage of mankind element is an inter- 
national management regime incorporating "representatives from all nations". Because developed states often have greater access to common heritage of mankind resources, international management is intended to provide developing states with a measure of control over exploitation [18. P. 231]. At the present time, there is no international entity to administer the legal status of outer space strongly or dispute settlements among States. Disagreement of developed countries' and inefficiency of current entities are the main reasons for this shortage in outer space.

\subsection{Solutions to Realizing of the Common Heritage of Mankind in Outer Space}

As we have discussed before, the concept of common heritage of mankind doesn't have a strong position in the international legal system and application of this concept has associated with some challenges. It seems that by considering some items such as founding the Authority of Outer Space, amendment in Moon Agreement and explanation of the common heritage of mankind's elements, we can strengthen this concept in outer space legal system.

\subsubsection{Amendment in Moon Agreement}

Moon Agreement has addressed issues related to the concept of common heritage of mankind more than other documents but it has not welcomed by space powers. This Agreement required some amendment (According to the provisions of 17 and 18 of the Agreement) in order to encourage countries to join it. These amendments would be effective if consider some items such as: regulate the system of property, changing in the concept of equitable sharing of benefits and consideration of the benefits of private enterprises.

Regulate the system of property has been considered by developed countries. In January 2004, the US President George W. Bush announced his vision for the future of space exploration and the development of space resources and infrastructure and created the Commission on Implementation of United States Exploration Policy which recommends that Congress increase the potential for commercial opportunities related to the national space exploration vision by: 1. providing incentives for entrepreneurial investment in space; 2 . creating significant monetary prizes for the accomplishment of space missions and/or technology developments; and 3. assuring appropriate property rights for those who seek to develop space resources and infrastructure. The report also recommends protecting and securing the property rights of private industry in space and recognizes that the issue of private property rights in space is a complex one involving national and international issues. A general view in this regard is that the implementation of this vision requires an overhaul of the current treaties and laws that govern property rights in space in order to develop better and more workable models that will stimulate commercial enterprise on the moon, aster- 
oids, and Mars [16. P. 214]. It seems that ratifying an additional agreement similar to 1994 Agreement Relating to the Implementation of Part XI of the UNCLOS (that moderated the extreme approaches of UNCLOS against the concept of common heritage of mankind) regarding Moon Agreement can integrate classical concepts of common property with limited property legal regimes.

Wording of equitable sharing of benefits in the Moon Agreement implies a mandatory sharing of benefits and transferring of technology to developed countries. Technology transfer to developing countries should not be obligatory. Modern technologies represent valuable assets that must be equally protected by existing laws governing intellectual property rights. The entities, having worked, risked, and spent money on research and development, should be allowed to maintain their technologies and retain any profits from them. Developing countries should obtain technology at market price, but the price should be fair and reasonable. Other ways can be formulated to promote the transfer of technology to developing countries, such as establishment of joint ventures with developing countries [19. P. 289].

Although some researchers argue that the financial exploitation and commercialization of space by private entities are not in conformity with benefit of mankind, but international procedure accepted their presence at the time of concluding the Outer Space Treaty. Despite the importance of commercialization and privatization of spatial activities and increasing private enterprises participation in the field of satellite communications, remote sensing and launching of objects, international space treaties are mainly state-centric. Private enterprises have little place in these treaties and their benefits are not considered adequately. The Moon Agreement in articles 11 and 14 takes into account the private enterprises briefly and put some restrictions on their property rights and licensing procedure without paying attention to their rights. Given the efforts and success of private enterprises in space fields, it is vital to consider their benefits in the amendments of Moon Agreement.

\subsubsection{Founding the Authority of Outer Space}

Founding an international authority to administer outer space affairs is an inevitable necessity. Accordingly, it deserves consideration that establishing this authority should be based on those criteria that cover needs of developing and developed countries equally. The most important necessities that justify the creation of an international authority are demilitarization of outer space and monitoring economic activities.

At the United Nations, the initial inspiration behind the proposal to create a World Space Organization in 1985 was a campaign against the militarization of outer space. This inspiration remains valid today and forms the basis of any concept of international cooperation in managing outer space as a global resource. The essential concepts for a meaningful management regime for outer space namely, disarmament and development overlaid by the common heritage of mankind philosophy and the concept of «comprehensive security» are already in place and the concrete proposal 
for the creation of a World Space Organization has already been tabled at the United Nations General Assembly [20].

Realizing the commercial potential of outer space is an issue in need of urgent resolution. It is important to devise a regime for the exploitation of outer space by reaching a balance between protecting the profits of relevant exploiting entities and serving the interests of humankind. Existence of a stable governance regime can, as in the case of the deep seabed, enhance the confidence of space investors and promote further development of commercial space activities [19. P. 287]. A practical solution is having an authority in the lines of the International Seabed Authority, which would create economic incentive for nations and firms to simultaneously invest in outer space. The primary purpose of the organization, would be to regulate the use and exploration of outer space and therefore, all the space-faring nations should be part of the treaty. Alternatively stated, one may state that in order for a State or its citizens to carry on commercial activities in space, the State should be a member of the treaty. The proposed, International Space Resource Management Organization maybe formed under the aegis of the General Assembly and later when feasible may be made as a specialized organ of the United Nations. In order for the International Space Resource Management Organization to truly fulfil its goals, it must be able to effectively monitor the activities by commercial entities in space. This Organization should be empowered to visit the outer space sites of commercial enterprises to ensure that the rules and procedures with regard to Outer Space Activities are strictly complied with [16. P. 217].

\subsubsection{Explanation of the Common Heritage of Mankind's Elements}

The common heritage of mankind's elements has always been associated with ambiguities. There are two processes to resolve these ambiguities: explanation in domestic law and international law.

Without a doubt, the entry of a concept of international law into domestic legal system and practice it can contribute to the confirmation of this concept. The United States National Aeronautics and Space Act of $1958^{5}$ (NASA) provides an example of this process. A provision of that act states: "The Congress declares that it is the policy of the United States that activities in outer space should be devoted to peaceful purposes for the benefit of all mankind." Another section of that act declares that one objective of the United States space program is "cooperation by the United States with other nations ... in work pursuant to this act and the peaceful application thereof." These provisions reflect a convergence of national legislation with international space law principles [6. P. 425].

\footnotetext{
${ }^{5}$ National Aeronautics and Space Act of 1958. Pub. L. No. 85-568, 72 Stat. 426-438 (Jul. 29, 1958).
} 
The common heritage of mankind's elements and related categories that hold close relationship with this concept, can be defined by those documents that issued by those international institutes that are engaged in space law affairs. Due to the lacking capacity of the United Nations General Assembly to enact its own distinct legislation, such resolutions lack legally binding force. However, they are still important for a certain opinio juris of a significant number of States, even more so if these resolutions are adopted by consensus. Therefore, space activities like the use of nuclear power sources, the use of telecommunications satellites, or of remote sensing satellites, as well as other possible commercial uses, are not confronted with a complete legal vacuum. Rather, the constant conduct and respect for such resolutions may build up to eventually become customary international law. In this regard, a short word must be said about some earlier observations of the space law age. Here, the famous legal scholar Bin Cheng had observed that after the adoption of a United Nations General Assembly resolution for activities in outer space, this resolution would instantly become customary international law. There is a correct part of this observation, namely, that for such resolutions, even more so if adopted by consensus to be significant for a respective opinio juris of States, one still needs the time element, that is a certain period of time over which such resolutions are observed by States in order to speak of the development of a respective custom [21. P. 5].

\section{CONCLUSION}

The Moon Agreement was the first attempt to expand the scope of outer space law by declaring that the natural resources of outer space are the common heritage of mankind. This principle, however, has not been unanimously accepted by space powers. Developed countries have been reluctant to accept what they see as an attempt by developing states to force a division of benefits extracting from space exploitation. Ambiguity of the meaning of common heritage has caused space powers to defer ratification of the Moon Treaty, thereby effectively preventing the treaty from entering into force. In addition, among five elements of common heritage of mankind, only non-appropriation element has been accepted by the world community and the rest of the elements have been neglected through political, economic and military reasons. Lack of an authority to realize cooperative management of area is another challenge of the concept. The author suggests three solutions that they ensure the space law would remain a viable branch of international law. These solutions are as follows: amendment in moon agreement, founding the authority of outer space, explanation of the common heritage of mankind's elements. There is support for these suggestions in the literature on space law and in the language of the Outer Space Treaty and the Moon Agreement.

In the conclusion I would like to quote prof. P. Taylor, he refers to the realization of the concept of the common heritage of mankind in international environmental law. It's quite similar to international space law. He said, that the concept of the 
common heritage of mankind "is far from reality if we expect the realization of these solutions in near future and common heritage of mankind may be a concept whose time is yet to come" [22. P. 328].

\section{REFERENCES}

[1] Bhat SB. The Concept of Common Heritage of Mankind in the Governance of the Moon An Insight into Article 11 of the Moon Agreement. Legal Opus. 2007;1:92-107.

[2] Zhukov GP, Abashidze AKh. International space law. Moscow: RUDN; 2014. 524 p. (In Russian).

[3] Ervin S. Law in a Vacuum: The Common Heritage Doctrine in Outer Space Law. Boston College International and Comparative Law Review. 1984;7(2):403-431.

[4] Nandakumar S. Common Heritage of Mankind - Property Rights, in the Wake of Commercial Use of the Moon and Other Celestial Bodies. In: Proceedings of the Forty-Eighth Colloquium on the Law of Outer Space. Reston: American Institute of Aeronautics and Astronautics. 2005. p. 308-317.

[5] Rana HS. The Common Heritage of Mankind \& (and) the Final Frontier a Revaluation of Values Constituting the International Legal Regime for Outer Space Activities. Rutgers Law Journal. 1994;26(1): 225-250.

[6] Goldie LFE. A Note on Some Diverse Meanings of the Common Heritage of Mankind. Syracuse Journal of International Law and Commerce. 1983;10(1):69-112.

[7] Arnold RP. The Common Heritage of Mankind as a Legal Concept. The International Lawyer. 1975;9(1):153-158.

[8] Goldie LFE. A General International Law Doctrine for Seabed Régimes. The International Lawyer. 1973;7(4):796-824.

[9] Gorove S. Concept of Common Heritage of Mankind Political Moral or Legal Innovation. The San Diego Law Review. 1972;9(3):390-403.

[10] Pardo A. Third World Lecture 1984. Ocean Space and Mankind. Third World Quarterly. 1984;6(3):559-575.

[11] Jakhu R. Legal Issues Relating to the Global Public Interest in Outer Space. Journal of Space Law. 2006;32(1):31-110.

[12] Dietrich GB. Extending the Principle of the Common Heritage of Mankind to Outer Space. Montreal, Quebec: McGill University; 2002. 91 p. Available from:http://digitool.library.mcgill.ca/webclient/StreamGate?folder_id $=0 \&$ dvs $=14857830733$ 03 907 [Accessed 18th November 2016].

[13] Hearsey ChM. A Review of Challenges to Corporate Expansion into Outer Space. In: AIAA SPACE Conference \& Exposition 9 - 11 September 2008. San Diego, California. Available from: http://www.astrosociology.org/Library/PDF/Hearsey_CorporateExpansion.pdf [Accessed 18th November 2016].

[14] Shackelford SJ. The Tragedy of the Common Heritage of Mankind. Stanford Environmental Law Journal. 2009;28(1). Available from: https://ssrn.com/abstract=1407332 [Accessed 18th November 2016].

[15] Gabrynowicz JI, Serrao JE. An Introduction to Space Law for Decision Makers. Journal of Space Law. 2004;30(2):227-233.

[16] Cherian G, Abraham J. Concept of Private Property in Space - An Analysis. Journal of International Commercial Law and Technology. 2007;2(4):211-220.

[17] Brandt-Erichsen, David; Brief History of the L5 Society. Available from: http://www.nss.org/settlement/L5news/L5history.htm [Accessed 18th November 2016]. 
[18] Jacobs B. The Future of Energy Lunar Resource Management and the Common Heritage of Mankind. Georgetown International Environmental Law Review. 2012;24(2):221-244.

[19] Zhao Y. An International Space Authority: A Governance Model for a Space Commercialization Regime. Journal of Space Law. 2004;30(2):277-296.

[20] Payoyo PB, editor. Ocean Governance: Sustainable Development of the Seas. Tokyo, New York, Paris: United Nations University Press; 1994. Available from:http://archive.unu.edu/unupress/unupbooks/uu15oe/uu15oe00.htm\#Contents [Accessed 18th November 2016].

[21] Hobe S. Current and Future Development of International Space Law. Available from: http://www.unoosa.org/pdf/publications/st_space_28E.pdf [Accessed 18th November 2016].

[22] Taylor P. The concept of the common heritage of mankind. In: Fisher D, editor. Research Handbook on Fundamental Concepts of Environmental Law. Cheltenham, UK, Northampton, MA, USA: Edward Elgar Publishing; 2016. p. 306-334.

(C) Mirzaee Siavash, 2017

\title{
INFORMATION ABOUT THE AUTHOR:
}

Mirzaee Siavash - Post-graduate student, International Law Department, Law Institute, RUDN University.

Contact information:

e-mail: siavash.mirzaei1988@gmail.com

\section{КОСМИЧЕСКОЕ ПРОСТРАНСТВО И ОБЩЕЕ НАСЛЕДИЕ ЧЕЛОВЕЧЕСТВА: ВЫЗОВЫ И РЕШЕНИЯ}

\author{
Сиаваш Мирзаи \\ Российский университет дружбы народов \\ Юридический институт \\ ул. Миклухо-Маклая, 6, Москва, Россия, 117198
}

\begin{abstract}
Цель статьи заключается в исследовании концепции общего наследия человечества в рамках международного космического права. В этой статье используется научно-методический подход, который позволяет выявить основные аспекты и понятия в рамках анализируемой проблематики. Использованная методология позволила широко исследовать реализацию концепции общего наследия человечества в практике государств и международных организаций.

С тех пор как человечество стало покорять космос и «открыло окно» для этой бесконечной области исследования, начался процесс международно-правового регулирования деятельности по использованию космического пространства. Одним из важных результатов этих усилий стало принятие в рамках ООН Соглашения о деятельности государств на Луне и других небесных телах от 5 декабря 1979 г., в соответствии с которым Луна и другие небесные тела стали признаваться общим наследием человечества. Однако Соглашение о Луне не было ратифицировано государствами, занимающимися пилотируемой космонавтикой, его ратифицировали несколько государств, оказывающих незначительное влияние на космическую деятельность.
\end{abstract}


В статье подробно анализируется концепция общего наследия человечества, которая включает в себя пять элементов: неприсвоение, международное управление ресурсами, распределение финансовых и технологических преимуществ, использование в мирных целях и в интересах нынешнего и будущих поколений. Показывается, что применение концепции общего наследия человечества к Луне и другим небесным телам, что так важно для развивающихся стран с целью сохранения ресурсов, всегда было связано с некоторыми проблемами.

Кроме того, с одной стороны, предпринимается попытка тщательного изучения подобных препятствий, которые мешают применению этой концепции. С другой стороны, автор предлагает некоторые решения для укрепления реализации этой концепции в космическом пространстве и мотивации космических держав к ратификации этого Соглашения.

Ключевые слова: Соглашение о Луне; Договор по космосу; общее наследие человечества; международное космическое право; совместное использование выгод; развивающиеся государства; Луна

\section{СВЕДЕНИЯ ОБ АВТОРЕ:}

Мирзаи Сиаваш - аспирант кафедры международного права Юридического института РУДН.

Контактная информация:

e-mail: siavash.mirzaei1988@gmail.com 